\title{
Metodologi Tafsir “Al-Furqan Tafsir Qur' an” (Membaca Karya A. Hassan 1887-1958)
}

\author{
Akhmad Bazith \\ Dosen Tetap Universitas Muslim Indonesia \\ bazith@yahoo.com; akhmad.bazith@umi.ac.id
}

\begin{abstract}
Abstrak
Kitab tafsir yang monumental ini sedikit banyaknya mempengaruhi sejarah penafsiran al-Quran di Indonesia dan A. Hassan sebagai seorang ulama penulis masih dikenang hingga hari ini. Sepanjang hidupnya sosok A. Hassan menjadi sangat istimewa karena peranannya yang begitu penting dalam sejarah tafsir al-Qur'an di Indonesia. Beliau tidak saja dikenal sebagai seorang ulama penulis, politikus, namun juga sebagai tokoh pembaharu di Indonesia. Hasil karya terbesar beliau selesai ditulis sebanyak satu jilid lengkap dan mencakup seluruh ayat suci al-Qur'an 30 juz. Kitab tafsir ini ditulis dalam kurun waktu antara tahun 1920-an sampai dengan tahun 1950-an. Kajian metodologi tafsir yang digunakan oleh A.Hassan dalam kitabnya Al-Furqān Tafsir Qur'an, metode yang digunakan adalah metode terjemahan harfiyah, meski pada beberapa penafsirannya terdapat pula terjemahan maknawiyah. Dalam menjelaskan ayat-ayat al-Qur'an cenderung ringkas dan padat, sehingga metode yang digunakan dalam tafsir ini termasuk dalam kategori metode tafsir ijmali.
\end{abstract}

Kata Kunci: Tafsir; Metodologi.

\section{Pendahuluan}

Dalam sejarah perkembangan tafsir dan dinamika kehidupan manusia, maka diskursus tafsir al-Qur'an semakin memberikan wacana baru bagi upaya untuk mempertahankan nilai-nilai universal dan transendental dari al-Qur'an. Dalam hal ini ada dua dimensi sebagai tren yaitu; pertama, komitmen untuk mempertahankan nilai-nilai spiritual dan sosio kultural al-Qur' an yang bersifat universal dan transendental. Kedua, diperhadapkan pada perubahan sejarah peradaban manusia baik dari latar belakang geografis maupun tingkat pengetahuan, maka diperlukan peningkatan kreatifitas yang tinggi dan orisinalitas cara memahami dan menafsirkan al-Qur'an.

Al-Qur'an dalam konteks kehidupan sosial senantiasa relevan dan tidak akan pernah bertentangan, baik yang berkaitan dengan makna tekstual maupun kontekstualnya. Sehingga dalam studi tafsir sebagai kegiatan ilmiah, relevansinya dengan metode pengetahuan menghasilkan pengetahuan baru yang bersumber dari al-Qur'an. Demikian pula, studi tafsir juga menuntut pemahaman yang komprehensif, termasuk kontekstualitasnya yang relevan dengan corak yang dipergunakan oleh seorang peneliti al-Qur'an. Untuk itu, metodologi tafsir al-Qur'an harus memiliki konstruksi epistemologis, agar supaya konsep-konsep dalam al-Qur'an lebih signifikan bila dikaitkan dengan perkembangan kehidupan sosial. ${ }^{1}$

Metode penulisan tafsir al-Qur'an sendiri relatif dinamis, baik dari aspek analisis maupun corak tafsirnya. Olehnya itu harus diakui bahwa setiap generasi tentu memiliki ciri atau karakteristik tafsir yang beraneka ragam. Indikasinya terdapat pada beberapa karya tafsir yang signifikan pada generasi berikutnya, agar dapat mengenal dan mengembangkan corak dan metode tafsir tersebut.

Sementara sejarah penerjemahan al-Qur'an di Indonesia ke dalam bahasa Melayu, sudah dimulai sejak pertengahan abad ke-17 yang diprakarsai oleh Abdul Rauf Singkel seorang ulama dari Singkel, Aceh. Meski mungkin terjemahan dalam bahasa Indonesia modern belum sempurna, namun pekerjaan terjemahan ini sungguh besar jasanya sebagai perintis jalan. Di antara karya terjemahan

${ }^{1}$ Abdul Muin Salim, Metodologi Tafsir; Sebuah Rekonstruksi Epistemologis Memantapkan Keberadaan Ilmu Tafsir sebagai Disiplin Ilmu, Orasi Ilmiah Pengukuhan Guru Besar (Ujungpandang: IAIN Alauddin, 1999), h. 2. 
yang dikenal adalah seperti Qur'an Kejawen dan Qur'an Sundawiyah yang dilakukan oleh Kemajuan Islam Yogyakarta; tafsir Hidayatur Rahman oleh KH. Moenawar Chalil yang diterbitkan oleh percetakan AB. Sitti Syamsiah Solo; Tafsir Qur'an Indonesia oleh Mahmud Yunus (1935), AlFurqan oleh A. Hassan Bandung (1928); Tafsir al-Qur'an oleh H. Zainuddin Hamid cs. (1959); Hibarna yang disusun oleh KH. Iskandar Idris; Tafsir al-Qur'an al-Hakim oleh HM. Kasim Bakry cs. $(1960){ }^{2}$

Memahami uraian di atas, dalam kajian ini akan diangkat satu kitab tafsir yang akrab di kalangan para alim ulama, pesantren dan masyarakat muslim pada umumnya yaitu Al-Furqān Tafsir Qur'an. Kitab ini adalah sebuah karya monumental dari seorang guru Persatuan Islam (Persis) yaitu A. Hassan, beliau yang juga dikenal sebagai tokoh intelektual muslim terkemuka di Indonesia. Karya tafsir ini ditulis dalam kurun waktu antara tahun 1920-an sampai dengan tahun 1950-an, merupakan salah satu langkah awal yang sangat bersejarah dalam penerjemahan al-Qur'an ke bahasa Indonesia. Pada masanya, karya ini sangat popular karena menggunakan metode dan bahasa yang sesuai dengan situasi sosial budaya masyarakat muslim Indonesia pada saat itu. Sepanjang hidupnya sosok A. Hassan menjadi sangat istimewa karena peranannya yang begitu penting dalam sejarah tafsir al-Qur'an di Indonesia. Beliau tidak saja dikenal sebagai seorang ulama penulis, politikus, namun juga sebagai tokoh pembaharu di Indonesia. ${ }^{3}$

Hasil karya terbesar A. Hassan ini, selesai ditulis sebanyak satu jilid lengkap dan mencakup seluruh ayat suci al-Qur'an 30 juz. Kitab tafsir yang monumental ini sedikit banyaknya mempengaruhi sejarah penafsiran al-Quran di Indonesia dan A. Hassan sebagai seorang ulama penulis masih dikenang hingga hari ini. Dan ini merupakan implementasi dari salah satu pesan Syekh Yūsuf al-Makassarì yang menyatakan bahwa seorang ulama harus menulis agar dikenang, atau menghilang dari sejarah. ${ }^{4}$ Berdasarkan latar belakang di atas, maka permasalahan pokok yang akan diangkat sebagai kajian adalah; bagaimana metode, kandungan dan teknik penafsiran kitab AlFurqān Tafsir Qur'an, karya A. Hassan.

\section{Pembahasan}

\subsection{Biografi A. Hassan}

Nama lengkapnya adalah Hassan bin Ahmad yang kemudian lebih dikenal dengan sebutan Hassan Bandung saat tinggal di kota Bandung. Setelah pindah menetap di Bangil, biasa dipanggil dengan Ahmad Hassan Bangil. Beliau lahir di Singapura pada tahun 1887. Beliau adalah ulama yang dikenal sangat berpendirian teguh dan ahli dalam berbagai ilmu keagamaan. Tokoh Islam terkemuka dari kalangan Persatuan Islam (Persis) ini, juga terkenal sebagai politikus ulung. ${ }^{5}$

Ayahnya bernama Ahmad Sinna Vappu Maricar yang digelari 'Pandit' berasal dari India, dan ibunya bernama Hajah Muznah kelahiran kota Surabaya tapi berasal dari Palekat Madras (India). Mereka menikah di Surabaya ketika Ahmad sedang melakukan perjalanan dagangnya di kota tersebut. Usai menikah, Ahmad memboyong istrinya ke Singapura. Selain berdagang, Ahmad (ayah Hassan) adalah seorang wartawan, penerbit surat kabar dan buku-buku dalam bahasa Tamil. Ia adalah pemimpin Koran Nurul Islam yang terbit di Singapura. Beliau juga ahli dalam hal agama dan bahasa. ${ }^{6}$ dan ia terkadang terlibat perdebatan mengenai dua ilmu ini. Di dalam surat kabarnya, Ahmad mengasuh rubrik tanya jawab. Ibarat pepatah, "Buah tak akan jatuh jauh dari pohonnya."

${ }^{2}$ Kementerian Agama RI, Al-Qur'an dan Terjemahnya (al-Madinah al-Munawwarah: Mujamma' alMalik Fahd li al-Ṭibā‘āt al-Mușhạ), h. 36.

${ }^{3}$ Fauzan Saleh, Teologi Pembaruan; Pergeseran wacana Islam Sunni di Indonesia Abad XX (Cet. I; Jakarta: PT. Serambi Ilmu Semesta, 2004), h. 186.

${ }^{4}$ Ahmad M. Sewang, Syekh Yusuf; Ulama Pejuang Yang Energik (1626-1699), Makalah Seminar Syekh Yusuf PKB Wilayah Sulawesi Selatan, Makassar 25 Juli 2011.

${ }^{5}$ http://lembaranpersisbangil.blogspot.com/2010/10/biografi-hassan.html. Sunday, October 31, 2010 (diakses tgl 27 Nopember 2012). Lihat juga Abdul Aziz Dahlan (ed), Ensiklopedi Hukum Islam, Jilid 2 (Cet. I; Jakarta: Ichtiar Baru Van Hoeve, 1996), h. 532.

${ }^{6}$ Gelar Pandit dalam masyarakat India berarti orang yang tinggi ilmu agamanya. 
Begitu pula dengan Hassan, rupanya, juga mewarisi tradisi intelektual ayahnya. Sejak umur 7 tahun, Hassan sudah belajar al-Qur'an dan ilmu-ilmu agama. Kemudian dia masuk sekolah Melayu, dan belajar bahasa Melayu, Arab, Inggris, dan Tamil. ${ }^{7}$

Secara formal, Hassan tak pernah menamatkan pelajarannya di sekolah dasar yang ditempuhnya di Singapura itu. Hanya sampai kelas 4 sekolah rakyat dan tingkat empat pada English Elementary School. Setelah meninggalkan sekolah selama 11 tahun (1910-1921), ia bekerja sebagai pegawai toko, agen distribusi es, tukang vulkanisasi ban mobil. ${ }^{8}$

Pada usia 12 tahun, Hasan sudah ikut berdagang, menjaga toko milik iparnya, Sulaiman. Sambil berdagang, Hassan memperdalam ilmu agamanya pada Haji Ahmad di Kampung Tiung dan Haji Muhammad Thaib di Kampung Rokoh untuk belajar ilmu Nahwu dan Saraf. Kemudian A. Hassan beralih belajar bahasa Arab kepada Said 'Abdullah Munawi Mausili sekitar kurang lebih tiga tahun. Setelah itu, A. Hassan belajar kepada Syeikh Haji Hassan al-Malabary dan Syeikh Ibrahim al-Hindi. Semuanya ditempuh hingga kira-kira tahun 1910 M., ketika ia berumur 23 tahun. Walaupun pada masa ini A. Hassan belum memiliki pengetahuan yang luas tentang tafsīr, fiqh, farā'id, mantiq, dan ilmu-ilmu lainnya, namun dengan ilmu alat yang dia miliki itulah yang kemudian mengantarkannya memperdalam pengetahuan dan pemahaman terhadap agama secara otodidak. ${ }^{9}$ Setelah ilmunya dirasa cukup, pada tahun 1910, Hassan mengajar di madrasah, dari tingkat Ibtidaiyah sampai Șanawiyah. Yaitu Madrasah Assaqaf Malaya dan guru bahasa Melayu serta bahasa Inggris di Pontian Kecil Sanglang Johor Bahru. ${ }^{1}$

Sepanjang hidupnya, A. Hassan hanya mempunyai seorang istri, yaitu bernama Maryam, menikah di Singapura pada tahun 1911. Maryam adalah seorang peranakan Tamil-Melayu, dari keluarga yang taat berpegang pada agama. Dari pernikahannya ini A. Hassan dikaruniai tujuh orang putra-putri; 1). Abdul Qadir Hassan, ${ }^{1}$ 2). Jamilah, 3). Abdul Hakim, 4). Zulaikha, 5). Ahmad, 6). Muhammad Sa'id, 7). Manshur. ${ }^{1}$

Pada tahun 1912, A. Hassan bekerja di Utusan Melayu yang diterbitkan oleh Singapore Press. A. Hassan menulis artikel yang berisikan nasihat-nasihat, mengajak pada kebaikan, dan menjauhi kemunkaran. Tidak jarang, Hassan menulis dalam bentuk puisi yang cukup menggelitik dan menyentuh. Dalam perkembangannya, tulisan Hassan mulai menemukan bentuknya. Yaitu memiliki sikap yang tegas terhadap persoalan yang, menurut dia, masuk ke wilayah prinsip. A. Hassan, misalnya, mengecam keras terhadap Qadli (hakim) yang memeriksa perkara dan mengumpulkan antara pria dan wanita di tempat duduk yang sama. Di surat kabar ini, Hassan bekerja sampai tahun 1916.

Suratan takdir A. Hassan rupanya tidak hanya bermukim di Singapura. Pada tahun 1921, A. Hassan berangkat pindah ke Surabaya, mengelola toko milik paman yang sekaligus gurunya, Abdul Lathif. Sebelum berangkat, Abdul Lathif berpesan pada sang keponakan, jangan bergaul dengan Pakih Hasyim yang dianggap sesat karena berfaham Wahabi. Rupanya, di Surabaya, waktu itu, sedang terjadi konflik antara kaum tua dengan kaum muda yang dipelopori oleh Pakih Hasyim, seorang pedagang yang sekaligus pendakwah. Pakih Hasyim, yang berasal dari Padang Sumatera Barat menggunakan rujukan dari buku-buku yang dikarang oleh Abdullah Ahmad, Abdul Karim

\footnotetext{
${ }^{7}$ www.maulana2008.co.cc (diakses tgl 27 Nopember 2012)

${ }^{8}$ Abdul Aziz Dahlan (ed), Ensiklopedi Hukum Islam, Jilid 2, h. 532-533

${ }^{9}$ Syafiq A. Mughni, Hassan Bandung: Pemikir Islam Radikal (Cet. II; Surabaya: PT. Bina Ilmu, 1994 M), h. 13 .

1 www.maulana2008.co.cc (diakses tgl 27 Nopember 2012)

1 Abdul Qadir Hassan (w. 25 Agustus 1984 M.), merupakan pelanjut A. Hassan, aktif menulis dalam bidang Tafsīr, Hadīs, Ilmu Hadīs, dan Ushūl Fiqh, di antara karya tulisnya adalah Kata Berjawab, Ilmu Mushthalah Hadits, Qāmūs Al-Qur'an, Ushūl Fiqh, Tafsīr Ahkām, Cara Berdiri I'tidal, dan masih banyak lagi yang lain. Putra Abdul Qadir Hassan, antara lain adalah Prof. Dr. Ir. Zuhal Abdul Qadir, M.Sc.,E.E., pernah menjabat sebagai Menteri Riset \& Teknologi pada masa Presiden Habibie; putranya yang kedua adalah Ghāzie Abdul Qadir (alm).

1 Syafiq A. Mughni, Hassan Bandung: Pemikir Islam Rådikal, h. 12.
} 
Amrullah, dan Zainuddin Labay -ketiganya asal Sumatera- dan Ahmad Soorkati, ulama asal Sudan yang bermukim di Batavia (Jakarta). A. Hassan datang ke Surabaya, awalnya, semata-mata hanya sebagai pedagang. Ia tinggal di rumah pamannya yang lain, Abdullah Hakim. Suatu hari, sang paman meminta agar A. Hassan menemui KH. A. Wahab Hasbullah (1888-1971). Belakangan, Kiai Wahab menjadi terkenal karena dia adalah salah seorang pendiri Nahdlatul Ulama (NU) pada tahun 1926.

Dalam pertemuan itu, Kiyai Wahab bertanya pada A. Hassan, hukum membaca 'ushalli'. "Pak kiyai, ushalli itu hukumnya sunnat," jawab A. Hassan. "Dasarnya apa?" pak Kiai kembali bertanya. "Kalau itu, bisa dicari di kitab mana pun," jawab A. Hassan. Dalam benaknya, A. Hassan bertanya-tanya, masalah yang ringan seperti ini kok ditanyakan? Rupanya, Kiyai Wahab sedang menjajaki A. Hassan. Pak kiyai juga menyampaikan pada A. Hassan, bahwa di Surabaya, sedang terjadi "perang dingin" antara kaum tua dengan kaum muda. Kiyai Wahab lalu meminta A. Hassan untuk mencari dalil-dalilnya di dalam al-Qur' an dan hadis. A. Hassan minta waktu sehari, sehingga ia semalaman mencari dalilnya ushalli di kitab-kitab Sahih Bukhari-Muslim, juga ayat-ayat alQur'an. Ternyata, masalah ushalli tak ditemukannya. A. Hassan akhirnya sampai pada kesimpulan bahwa pandangan kaum muda ada di jalur yang benar. Maka, ia pun bersahabat dengan Pakih Hasyim yang mewakili golongan muda. ${ }^{1}$

Pada tahun 1923, A. Hassan berangkat ke Bandung unt uk mempelajari pertenunan, di sinilah ia berkenalan dengan tokoh pendiri organisasi Persis (Persatuan Islam), ${ }^{1}$ yaitu Kiyai Haji Muhammad Yunus. Dia lalu bergabung dengan organisasi ini yang kemudian membawa A. Hassan diangkat menjadi guru Persatuan Islam. ${ }^{1}$ A. Hassan masuk Persis tatkala ormas Islam ${ }^{5}$ ini berusia 3 tahun (1926). Dan rupanya, ia segera populer di kalangan kaum muda yang progresif karena pengaruh dan wibawanya dalam organisasi ini. Pada masa-masa berikutnya, A. Hassan identik dengan Persis, demikian pula Persis identik dengan A. Hassan. ${ }^{1}$

Di Persis, sebenarnya A. Hassan bukan tertarik karena pahamnya, akan tetapi karena ingin mengarahkan Persis menjadi gerakah iṣlah (pembaharuan). A. Hassan sadar bahwa pemikirannya harus dituangkan dalam sebuah gerakan agar bisa berkembang secara efektif. Pandangannya memberikan bentuk dan kepribadian yang nyata kepada Persis dan dalam waktu yang sama telah menempatkan Persis dalam barisan muslim modern. Kehadiran A. Hassan di Persis membuka babakan baru dalam sejarah perkembangan Persis di masa-masa berikutnya. Sebagai tokoh figur, dia mempersiapkan kader-kadernya. Dari hasil pengkaderan yang dilakukannya muncullah dua figur yang mewakili pemikiran politik A. Hassan yaitu Mohammad Natsir (1908-1993) seorang ulama intelektual dan negarawan, dan putranya sendiri Abdul Qadir Hassan yang mewarisi ayahnya dalam menekuni ilmu agama dan pendidikan. ${ }^{1}$

Pada tahun 1940 (atau 1941), Hassan pindah ke Bangil, Pasuruan, Jawa Timur, mendirikan dan mengasuh Pondok Pesantren Persis. A. Hassan menunaikan ibadah haji pada tahun 1956. Saat berada di Tanah Suci, A. Hassan jatuh sakit hingga terpaksa dibawa pulang kembali. Kemudian tertimpa lagi penyakit baru, yakni infeksi yang menyebabkan kakinya harus dipotong. Tokoh kharismatik ini meninggal dunia pada usia 71 tahun di Bangil (Jawa Timur), 10 November 1958, dan dimakamkan di Pekuburan Segok, Bangil.

${ }^{1}$ www.maulana2008.co.cc (diakses tgl 27 Nopember 20ß2)

1 Organisasi Persis (Persatuan Islam) berdiri pada tanggal 12 September 1923 di Bandung. Menurut M. Dawam Rahardjo, bahwa penamaan Persatuan Islam ini dengan merujuk pada maksud A. Hassan untuk menghilangkan kesan seolah-olah umat Islam di Indonesia telah terbelah menjadi dua kelompok atau mazhab yang saling berseberangan, yaitu Muhammadiyah dan NU. Olehnya itu, A. Hassan menyeru kepada umat Islam untuk kembali kepada satu Islam saja, karena itulah dia menyebut kelompoknya dengan nama Persatuan Islam. Lihat Fauzan Saleh, Teologi Pembaruan; Pergeseran wacana Islam Sunni di Indonesia Abad XX, h. 206.

1 Abdul Aziz Dahlan (ed), Ensiklopedi Hukum Islam, Jilid 2, h. 533.

1 Abdul Aziz Dahlan (ed), Ensiklopedi Hukum Islam, Jilíd 2, h. 533.

1 Abdul Aziz Dahlan (ed), Ensiklopedi Hukum Islam, Jilîd 2, h. 533. 
A. Hassan meninggalkan beberapa karya ilmiah berupa buku sekitar 81 buah dan majalahmajalah. Di antaranya;

a. Dalam bidang al-Qur'an dan Tafsir yaitu Al-Furqān Tafsir Qur'an, Tafsir al-Hidāyah, Tafsir Surah Yasin, dan Kitab Tajwid.

b. Dalam bidang Hadis, Fiqh, dan Ushul Fiqh yaitu Soal Jawab: Tentang Berbagai Masalah Agama, Risalah Kudung, Pengajaran Shalat, Risalah Al-Fatihah, Risalah Haji, Risalah Zakat, Risalah Riba, Risalah Ijma', Risalah Qiyas, Risalah Mazhab, Risalah Taqlid, Al-Jawahir, AlBurhan, Risalah Jum'at, Hafalan, Tarjamah Bulugh al-Maram, Muqaddimah Ilmu Hadis dan Ushul Fiqh, Ringkasan Islam, dan Al-Fara'id.

c. Dalam bidang Akhlaq yaitu: Hai Cucuku, Hai Putraku, Hai Putriku, Kesopanan Tinggi Secara Islam.

d. Dalam bidang Kristologi yaitu Ketuhanan Yesus, Dosa-dosa Yesus, Bibel Lawan Bibel, Benarkah Isa Disalib?, Isa dan Agamanya.

e. Dalam bidang Aqidah, Pemikiran Islam, dan Umum yaitu Islam dan Kebangsaan, Pemerintahan Cara Islam, Adakah Tuhan?, Membudakkan Pengertian Islam, What is Islam?, ABC Politik, Merebut Kekuasaan, Risalah Ahmadiyah, Topeng Dajjal, Al-Tauhid, Al-Iman, Hikmat dan Kilat, An-Nubuwwah, Al-'Aqa'id, al-Munazarah, Surat-surat Islam dari Endeh, Is Muhammad a True Prophet?

f. Dalam bidang Sejarah yaitu Al-Mukhtar, Sejarah Isra' Mi'raj.

g. Dalam bidang Bahasa dan Kata Hikmat: Kamus Rampaian, Kamus Persamaan, Syair, First Step Before Learning English, Al-Hikam, Special Dictionary, Al-Nahwu, Kitab Tashrif, Kamus Al-Bayan, dan lainnya. ${ }^{1}$

Dari karya-karya ilmiyah yang telah diwariskan A. Hassan tersebut, dapat dilihat betapa luas ilmu yang digelutinya. Menurut Howard M. Federspiel dan Syafiq A. Mughni, sebagaimana dikutip Fauzan Saleh, gaya tulisan A. Hassan seringkali membuat lawan-lawannya kecewa, bahkan sangat keras dalam membuat pernyataan, meski dalam banyak hal selalu bersikap obyektif dan tidak mengarahkan kritiknya kepada pribadi seseorang. Namun bagi pengagumnya, kritikan tajam dari A. Hassan semata-mata dimaksudkan untuk kemaslahatan seluruh umat secara umum. Polemiknya selalu disertai dengan kejujuran dan ketulusan untuk menunjukkan kebenaran yang diyakininya. Terlepas dari kritikannya yang tajam, A. Hassan tetap merupakan sosok yang rendah hati dan ramah di dalam kehidupan sosialnya. ${ }^{1}$

Demikian pula komentar Ahmad Soorkati, ulama asal Sudan yang juga pendiri Jamiyah alIrsyad bahwa, A. Hassan adalah seorang yang terpelajar, memiliki tingkat an tauhid yang tinggi dan seorang pembela agama Allah yang selalu berjuang menghindarkan umat Islam dari kesesatan. ${ }^{2}$

\subsection{Kajian atas Metode, Teknik Penafsiran dan Kandungannya}

Nashruddin Baidan dalam Metode Penafsiran al-Qur'an menyebutkan bahwa kata metode berasal dari bahasa Yunani 'methodos' yang berarti 'cara atau jalan'. Dalam bahasa Inggris kata ini ditulis 'method' dan dalam bahasa Arab diterjemahkan dengan 'thariqah' dan 'manhaj'. Dalam penggunaan bahasa Indonesia kata ini mengandung arti cara yang teratur dan terpikir baik-baik untuk mencapai maksud (dalam ilmu penget ahuan dan sebagainya); cara kerja yang bersistem untuk memudahkan pelaksanaan suatu kegiatan guna mencapai tujuan yang dit entukan. ${ }^{2}$

Sedangkan Abd Muin Salim menulis bahwa metode berasal dari kata method(Inggris). Kata ini tersusun dari kata Latin meta dan hodos. Masing-masing berarti 'sesudah' (مات) dan 'jalan,

${ }^{1} \mathrm{http} / / /$ lembaranpersisbangil.blogspot.com/2010/10/biografi-hassan.html. Sunday, October 31, 2010 (diakses tgl 27 Nopember 2012).

${ }^{1}$ Lihat Fauzan Saleh, Teologi Pembaruan; Pergeseran wacana Islam Sunni di Indonesia Abad XX, h. 206-207.

2 www.maulana2008.co.cc (diakses tgl 27 Nopember 2092)

${ }^{2}$ Lihat Nashruddin Baidan, Metode Penafsiran al-Qur'an (Cet. II; Yogyakarta: Pustaka Pelajar, 2011), h. 54 . 
petunjuk (هدى). Gabungan kedua kata tersebut membentuk kata methodos yang berarti suatu cara mengerjakan sesuatu obyek. ${ }^{2}$ Sedangkan metodologi dalam tafsir terdiri dari bẻberapa unsur yaitu metode, pendekatan, dan corak penafsiran.

Dari pemaparan ini terlebih dahulu akan diuraikan beberapa hal menyangkut tafsir ini;

\subsubsection{Latar Belakang Penulisan Tafsir}

Tafsir yang ada di tangan penulis saat ini bersampul warna hitam dengan khat kūfi kuning keemasan pada tulisan al-Furqān di bagian tengah, dan di bawahnya tertulis Al-Furqān Tafsir Qur'an A. Hassan, dengan tulisan Edisi Bahasa Indonesia Mutakhir di bagian atasnya. Dan pada halaman cover belakang terdapat tulisan persembahan dari Rektor Universitas al-Azhar Indonesia, Prof. Dr. Ir. Zuhal Abdul Qadir, M.Sc.,E.E. Tafsir ini terdiri dari 1009 halaman, belum termasuk halaman romawi mulai i sampai dengan romawi xc.

Al-Furqān Tafsir Qur'an adalah karya besar dan penting yang dimiliki oleh A.Hassan. Penulisan tafsir ini merupakan langkah pertama dalam sejarah penerjemahan al-Qur'an ke dalam bahasa Indonesia dalam kurun waktu 1920-1950-an. Yang terbagi ke dalam beberapa edisi penerbitan sampai sekarang. Bagian pertama diterbitkan pada tahun 1928, akan tetapi dalam edisi pertama ini belum seperti yang diharapkan, karena baru dapat memenuhi sebagian ilmu yang diharapkan oleh umat Islam Indonesia. Kemudian untuk memenuhi desakan anggota Persatuan Islam, bagian kedua tafsir tersebut diterbitkan pada tahun 1941, namun hanya sampai surat Maryam. Selanjutnya pada tahun 1953, penulisan kitab tafsir tersebut dilanjutkan kembali atas bantuan seorang pengusaha yang bernama Sa'ad Nabhan hingga akhirnya tulisan tafsir ini dapat diselesaikan secara keseluruhan yaitu 30 juz, dan diterbitkan pada tahun $1956 .^{2}$ Kemudian tahun 2006, tafsir ini kembali diterbitkan oleh Pustaka Mantiq bekerjasama dengan Universitas al-Azhar Indonesia. $^{2}$ Yang terakhir di tangan penulis adalah Cetakan ke-2 Maret 2010 yang diterbitkan oleh Universitas al-Azhar Indonesia (UAI), dalam satu jilid lengkap.

Menurut Zuhal Abdul Qadir, bahwa mengingat tafsir ini ditulis pada dekade 1960-an, bahasa Indonesia yang digunakan pun sesuai dengan ketentuan yang berlaku pada masa itu. Pada periode berikutnya bahasa Indonesia mengalami perkembangan dan kemajuan, utamanya saat ditetapkan Pedoman Umum Ejaan Bahasa Indonesia yang Disempurnakan (Edisi Kedua, 1987), penulisan Tata Bahasa Baku Bahasa Indonesia (Edisi Pertama, 1988), Kamus Besar Bahasa Indonesia (Edisi Pertama, 1988) dan Pedoman Transliterasi Arab-Indonesia 1987. Dalam hal ini misalnya banyak kosa kata yang digunakan dalam tafsir ini yang maknanya berbeda dengan makna yang difahami secara popular pada saat sekarang. ${ }^{2}$ Contohnya, ketua kaum yang berarti 'pemuka' at ău 'pemimpin kaum' atau sebarang syak ${ }^{2}$ yang berarti 'tidak ada keraguan sedikit pun', đ́tau struktur kalimat yang dapat menimbulkan pemahaman yang keliru seperti dalam QS.Bara'ah/9: 22 diartikan; 'hal keadaan mereka kekal padanya selama-lamanya, karena sesungguhnya Allah itu di sisi-Nya ada ganjaran yang besar'. ${ }^{2}$

Berdasarkan hal ini, maka pihak keluarga besar A. Hassan serta permintaan para peminat dan pemerhati tafsir ini berusaha mengadakan perbaikan dan penyempurnaan redaksional yang selaras dengan perkembangan bahasa Indonesia modern. Namun perbaikan ini hanya diarahkan kepada pemilihan kata yang tepat dan susunan kalimat yang sesuai dengan kaidah yang berlaku, dan tidak mengarah kepada hal yang sifatnya substansial. Hal ini berarti bahwa perbaikan yang dilakukan

2 Lihat Abd. Muin Salim, Metodologi Tafsir, h. $9 . \quad 2$

2 Zuhal Abdul Qadir, Sepatah Kata dari Kami, dalam ß̊. Hassan, Al-Furqān Tafsir Qur'an (Cet. II; Jakarta: Universitas Al-Azhar Indonesia, 2010), h. v.

2 www.maulana2008.co.cc (diakses tgl 27 Nopember 2042)

2 A. Hassan, Al-Furqān Tafsir Qur'an, h. v.

2 Dalam edisi muktahir diterjemahkan dengan ; tidak âda keraguan padanya. Lihat A. Hassan, AlFurqān Tafsir Qur'an, h. 3

2 Dalam edisi muktahir diterjemahkan dengan ; "Mereka pun kekal di dalamnya selamanya karena sesungguhnya di sisi Allah-lah balasan yang besar itu. Lihat A. Hassan, Al-Furqān Tafsir Qur'an, h. 305. 
namun tetap menjaga inti pemikiran A. Hassan yang dituangkan dalam karya tafsir ini. ${ }^{2}$ Sehingga pada akhirnya tafsir ini terbit dalam 'Edisi Bahasa Indonesia Mutakhir' yang diprakarsai oleh Prof. Dr. Ir. Zuhal Abdul Qadir, M.Sc.,E.E., selaku Rektor Universitas al-Azhar Indonesia (UAI) Jakarta yang juga ahli waris A. Hassan, dan tafsir ini telah memasuki cetakan kedua Maret 2010. Adapun pemutakhiran redaksional tafsir ini terwujud atas bantuan tim penyunting yaitu dari Tim Pusat Pengembangan Bahasa dan Budaya UAI sebagai berikut;

a. Dr. Thoyib I.M., MA sebagai Koordinator

b. Drs. Saifullah Kamalie, Lc., M.Hum. sebagai anggota

c. Dr. Afdol Tharik Wastono, M. Hum sebagai anggota

d. Nur Hizbullah, S.Ag., M. Hum sebagai anggota

e. Dr. Faisal Hendra, M. Ed sebagai anggota

f. Moch. Syarif Hidayatullah, Lc., M. Hum sebagai anggota. ${ }^{2}$

Pada dasarnya A. Hassan tidak menjelaskan secara komprehensif dan eksplisit mengenai latar belakang penulisan karya tafsir ini, akan tetapi hal ini bisa dilihat dari mukadimah tafsirnya "Sepatah Kata dari Kami" yang ditulis oleh cucu A. Hassan, yaitu Prof. Dr. Ir. Zuhal Abdul Qadir, M.Sc.,E.E., terdapat beberapa point latar belakang penulisannya yang dapat dirangkum yaitu :

a. Penulisan tafsir al-Qur'an sangatlah penting, untuk memenuhi sebagian ilmu yang diperlukan umat Islam Indonesia.

b. Adanya desakan sejumlah anggota Persis yang ingin sekali mempunyai pegangan bacaan sebuah tafsir, sehingga dapat memudahkan mereka memahami al-Qur'an.

c. Atas dorongan dan bantuan seorang pengusaha penerbit buku yang bernama Sa'ad Nabhan sehingga beliau mampu menyelesaikan sekaligus menerbitkan tafsir ini. ${ }^{3}$

Sekilas saat melihat dan membuka lembaran demi lembaran kitab tafsir ini, maka kesan awal yang tersirat adalah bahwa itu sebuah kitab terjemah al-Qur'an dan bukanlah kitab tafsir. Karena tidak ada kesan seperti kitab tafsir pada umumnya. Karya ini layaknya seperti terjemah al-Qur'an sebagaimana terjemahan terbitan Departemen Agama RI. (Kementerian Agama RI.) atau cetakan Madinah al-Munawwarah atau terbitan yang lainnya, yang dibubuhi dengan catatan kaki. Itupun tidak semua surah ada catatan kakinya, bahkan ada surah yang sama sekali tidak ada catatan kakinya, seperti surah Quraisy.

Sementara itu, mengenai penamaan tafsir "al-Furqān" sendiri, penulis tidak mendapatkan komentar dan alasan penamaan dari kitab tafsir ini, akan tetapi boleh jadi penamaannya diambil dari salah satu nama lain dari al-Qur'an yaitu al-Furqān yang berarti pembeda dari yang haq dan yang batil, atau boleh jadi mengambil dari salah satu nama surah yang ada dalam al-Qur'an yaitu surah ke-25 yaitu al-Furqān, yang ayat pertamanya menyebut kata al-Furqān. ${ }^{3}$

\subsubsection{Metodologi Penulisan Tafsir}

Secara umum, ada tiga jenis sistematika dalam penulisan kitab tafsir; Pertama, sistematika mushafi, yaitu penulisan kitab tafsir dengan berpedoman pada urutan susunan surah-surah dan ayatayat sebagaimana tertera dalam mushaf dimulai dari QS. al-Fātihah, al-Baqarah dan seterusnya hingga QS. al-Nās. Kedua, sistematika nuzū $/ i$ yaitu penulisan kitab tafsir dengan berpedoman pada kronologi turunnya ayat-ayat al-Qur'an. Ketiga, sistematika mauḍū' berdasarkan topik-topik tertentu dengan cara mengumpulkan ayat-ayat yang relevan dengan topik tertentu kemudian ditafsirkan. ${ }^{3}$

\footnotetext{
2 A. Hassan, Al-Furqān Tafsir Qur'an, h. v. $\quad 8$

2 A. Hassan, Al-Furqān Tafsir Qur'an, h. iv-v. 9

3 A. Hassan Al-Furqān Tafsir Qur'an, h. v. (Sepatah Kata dari Kami).

3 A. Hassan, Al-Furqān Tafsir Qur'an, h. 593.

${ }^{3}$ Mohammad Arja Imroni, Konstruksi Metodologi Tafsir al-Qurthubi (Cet.I: Semarang: Walisongo
} Press, 2010), h. 108. 
Bila dilihat dari sistematika di atas, maka tafsir yang dikaji ini termasuk dalam kategori sistematika mushafí, yang memulai tafsirnya dari QS. al-Fātihah, al-Baqarah dan seterusnya hingga QS. al-Nās sesuai dengan urutan surah dan ayat yang ada dalam mushaf al-Qur'an.

Untuk lebih dekat mengenal tafsir ini, berikut dikemukakan sistematika penulisannya. Tafsir ini adalah tafsir yang sangat komprehensif, karena di dalamnya termuat berbagai macam penjelasan mulai dari sejarah al-Qur'an, ilmu pengetahuan dalam al-Qur'an serta huruf yang terkait dengan penjelasan mengenai ayat al-Qur' an itu sendiri, dengan sistematikanya sebagaimana berikut:

a. Pada bagian awal cover dalam tafsir ini dicantumkan nama kitab, nama mufasir, nama-nama penyunting, serta penerbit, disertai dengan tahun cetakan.

b. Pada bagian muqaddimah tafsir ini memuat kata pengantar "Sepatah Kata dari Kami” yang ditulis oleh Prof. Dr. Ir. Zuhal Abdul Qadir, M.Sc.,E.E. Setelah itu "Pengantar Tim Penyunting", kemudian dilampirkan pula "Transliterasi". 3

c. Pada bagian "Pendahuluan" tafsir ini, diberi pendahuluan yang ditulis oleh A. Hasan sendiri. Adapun isi pendahuluannya terdiri dari 33 pasal. Setiap pasal menerangkan mengenai pembahasan tentang al-Qur'an, misalnya Pasal 1 tentang "Cara Menerjemahkan" dan pasal 4 yaitu penjelasan mengenai "Sejarah Turunnya al-Qur'an". 3

d. Setelah pendahuluan dilampirkan "Glosarium" yaitu keterangan beberapa kata-kata kunci dalam al-Qur'an atau kata-kata ilmiah yang disusun secara alphabet. Misalnya kata al-Haq artinya kebenaran yang nyata, Tuhan, wahyu. Kata mutasyābihāt yang berarti samar-samar. ${ }^{3}$

e. Setelah itu dalam tafsir ini diberikan juga "Petunjuk Pencarian Kata dalam al-Qur'an" yaitu tema-tema pokok al-Qur'an dengan mencantumkan ayat-ayatnya, atau dengan kata lain ini merupakan indeks al-Qur'an berdasarkan tema. Bagian ini ditulis oleh Abdul Qadir Hassan, dengan tujuan agar dapat memudahkan pencarian tema atau permasalahan di dalam al-Qur'an dengan merujuk kepada kitab Tafșil Ayāt al-Qur'an al-Ḥakim, hasil terjemahan Muhammad Fuad 'Abd al-Bāqii. ${ }^{3}$

f. Kemudian menempatkan tema-tema pokok berdasarkan keterangannya dan ayat-ayatnya pada bagian berikutnya pada "Penelusuran Pokok-pokok Ajaran Qur'an". Bagian ini ditulis oleh Zuhal Abdul Qadir, untuk memudahkan bagi peminat al-Qur'an yang berlatar belakang pendidikan non agama. Dengan mengelompokkan enam tema utama yaitu; prinsip-prinsip keimanan dan ketuhanan (tauhid), muslim dan peribadatannya, ilmu pengetahuan, asas-asas moralitas, aspek kemasyarakatan dan perekonomian dan aspek hukum dan kenegaraan. ${ }^{3}$

g. Setelah lengkap keseluruhannya barulah A. Hassan mencantumkan "Daftar Isi" yang berisikan nama surat dan arti dari nama surat itu sendiri dengan menggunakan bahasa Arab dan bahasa Indonesia. ${ }^{3}$

h. Setelah itu ia mulai melakukan penafsiran yang diawali dengan surat al-Fātihah dan diakhiri dengan surat al-Nās. ${ }^{3}$ Yang menarik dari tafsir ini, pada setiap awal st̛rat dimulai basmalah, seperti umumnya kecuali surah Bara'ah, kemudian ditulis nama setiap surah dan dicant umkan arti dari nama surat tersebut, jumlah ayatnya, tempat turunnya surah, lalu mukaddimah dan terjemahan (tafsirannya) serta pada bagian akhir diberikan catatan kaki pada setiap surat. Meski tidak semua surah didapatkan catatan kaki (footnote), misalnya surah al-Ikhlas, al-Kafirun, Quraisy. ${ }^{4}$ Sebagaimana telah dikemukakan sebelumnya, Bahwa ketika membuka lembaran demi lembaran kitab tafsir ini, kesan awal yang muncul adalah kitab ini bukanlah kitab tafsir sebagaimana lazimnya, bahkan dapat dikatakan sebagai kitab terjemah al-Qur'an (atau alQur'an dan terjemahnya).

\footnotetext{
${ }^{3}$ A. Hassan, Al-Furqān Tafsir Qur'an, h. v-x. 3

3 A. Hassan, Al-Furqān Tafsir Qur'an, h. xi-xxx. 4

3 A. Hassan, Al-Furqān Tafsir Qur'an, h. xxxi-xxxv. 5

3 A. Hassan, Al-Furqān Tafsir Qur'an, h. xxxvi-xl. 6

${ }^{3}$ A. Hassan, Al-Furqān Tafsir Qur'an, h. xli-lxix. $\quad 7$

3 A. Hassan, Al-Furqān Tafsir Qur'an, h. lxx-xc 8

3 A. Hassan, Al-Furqān Tafsir Qur'an, h. 1-1099. 9

4 A. Hassan, Al-Furqān Tafsir Qur'an, h. 1091, 1094, 1097.
} 
Dalam kitab ini, A. Hassan dalam menafsirkan al-Qur'an cenderung hanya mengalihbahasakan ayat-ayat al-Qur'an ke dalam bahasa Indonesia secara harfiyah, kecuali bila kata at au kalimat agak sulit dialihbahasakan secara harfiyah, maka ia berusaha memberikan makna yang dapat difahami dalam bentuk footnote (catatan kaki). A. Hassan menyatakan dalam "Pendahuluan" tafsirnya bahwa;

"Dalam menerjemahkan ayat, sedapat mungkin saya melakukannya kata demi kata. Jika cara itu tidak dapat dilakukan, barulah saya menerjemahkan suatu kata dengan melihat maknanya karena, menurut saya, cara itu akan berguna bagi orang yang teliti dalam melihat terjemahan. ${ }^{4}$

Pernyataan A. Hassan ini juga direspon oleh Noer Iskandar al-Barsany, ${ }^{4}$ sebagaimana diulas oleh Fauzan Saleh, bahwa A. Hassan memiliki cara tersendiri dalam menafsirkan ayat al-Qur'an. A. Hassan lebih banyak menggunakan penafsiran secara harfiyah dan beranggapan bahwa rasio berguna hanya di dalam memahami wahyu, tetapi tidak dalam menentukan kebenaran. Dan bagi mereka yang ingin menafsirkan al-Qur'an secara non literal hendaknya membaca dari beberapa kitab tafsir al-Qur'an selain al-Furqān. ${ }^{4}$

Dengan demikian dapat dikatakan, bahwa metode tafsir yang dipakai A. Hassan adalah metode harfiyah, yaitu penerjemahan kata demi kata. Kecuali terhadap beberapa kata yang tidak memungkinkan untuk diterjemahkan dengan metode ini, maka ia menggunakan metode maknawiyah.

Hal ini dilakukan oleh A. Hassan dengan maksud berusaha mempertahankan sepenuhnya nuansa teks asli dalam terjemahnya. Akan tetapi metode ini pula diakuinya tidak menghasilkan terjemahan yang mudah difahami oleh setiap orang yang membacanya, dan tidak begitu sejalan dengan kaedah-kaedah bahasa Indonesia. Sehingga dalam beberapa hal, A. Hassan menerjemahkannya secara maknawiyah. Misalnya, ia menerjemahkan a ق ال (qāla lahu). Ketika diterjemahkan kata perkata berarti "dia berkata baginya", tapi beliau menerjemahkan "(kawannya yang mukmin) berkata kepadanya". Contoh lain آن باله (ämana billāahi), biasanya diterjemahkan "dia percaya dengan Allah", tetapi beliau terjemahkan "(mereka) percaya kepada Allah". ${ }^{4}$ Dalam penerjemahan ayat-ayat al-Qur'an, A. Hassan memberikan tekanan yang berbeda. Seperti, menurut bahasa Arab, frasa المحد (al-Hamdu lillāhi) diterjemahkan dengan "segala puji (hanyalah) milik Allah", tetapi Lillāhil-hamdu diterjemahkan "kepunyaan Allah-lah segala pujian". Kata نبدك (na’buduka) diterjemahkan "kami menyembah-Mu" tapi إياك نعبد (iyyaka na’budu) diterjemahkan "Hanya Engkaulah yang kami sembah".

Pada hakikatnya, metode yang digunakan dalam penerjemahan harfiyah ini merupakan bagian dari pada metode ijmali (global). Yaitu sebuah metode penafsiran yang mencoba menjelaskan ayatayat al-Qur'an secara ringkas dan padat, tetapi mencakup (global). ${ }^{4}$ Metode ini juga mengulas setiap ayat al-Qur'an dengan sangat sederhana, tanpa ada upaya untuk memberikan pengkayaan

${ }^{4}$ A. Hassan, Al-Furqān Tafsir Qur'an, h. xi.

1

${ }^{4}$ Noer Iskandar al-Barsany adalah salah seorang pen²kaji pemikiran teologis A. Hassan dalam desertasinya dengan judul; "Pemikiran Teologi A. Hassan; Kajian Analitis untuk Mengetahui Posisi Pemikiran Teologi Islam A. Hassan” di IAIN Sunan Kalijaga Yogyakarta tahun 1997.

${ }^{4}$ Fauzan Saleh, Teologi Pembaruan; Pergeseran wacana3'Islam Sunni di Indonesia Abad XX, h. 193.

4 A. Hassan, Al-Furqān Tafsir Qur'an, h. 473 (dalam QS4. al-Kahfi/18: 37.

4 A. Hassan, Al-Furqān Tafsir Qur'an, h. 84 (dalam QS. ăl-Baqarah/2: 285.

4 A. Hassan, Al-Furqān Tafsir Qur'an, h. 1. 6

${ }^{4}$ Metode ijmăli adalah metode tafsir yang menałsirkan ayat-ayat al-Qur'an dengan cara mengemukakan makna global. Dengan metode ini penafsir menjelaskan arti dan maksud ayat dengan uraian singkat yang dapat menjelaskan sebatas artinya. Dalam uraiannya, penafsir membahas secara runtut berdasarkan urutan mushaf, kemudian mengemukakan makna global yang dimaksud oleh ayat tersebut. Lihat 'Abd Hayy al-Farmāwī, Muqaddimah fỉ al-Tafsìr al-Mauḍūí (Cet. III; t.t: tp, 1409 H/1988 M.), h. 42. Lihat juga M. Al-Fatih Suryadilaga (dkk), Metodologi Ilmu Tafsir (Cet. III; Yogyakarta: Teras, 2010), h. 45. 
dengan wawasan yang lain, sehingga pembahasan yang dilakukan hanya menekankan pada pemahaman yang ringkas dan bersifat global.

Dalam metode ini, A. Hassan berupaya untuk menjelaskan makna-makna al-Qur'an dengan uraian singkat dan mudah dipahami oleh pembaca dalam semua tingkatan, baik tingkatan orang yang memiliki pengetahuan yang ala kadarnya sampai pada orang yang berpengetahuan luas. Dengan kata lain, metode tafsir ijmali menempatkan setiap ayat hanya sekedar ditafsirkan dan tidak diletakkan sebagai obyek yang harus dianalisa secara tajam dan berwawasan luas, sehingga masih menyisakan sesuatu yang dangkal, karena penyajian yang dilakukan tidak terlalu jauh dari gaya bahasa al-Qur'an, sehingga membaca tafsir yang dihasilkan dengan memakai metode ijmali, layaknya membaca ayat al-Qur'an. Uraian yang singkat dan padat membuat tafsir dengan metode ijmali tidak jauh beda dengan ayat yang ditafsirkan. Proses penafsiran dengan menggunakan metode ijmali sebenarnya tidak jauh beda dengan metode-metode yang lain, terutama dengan metode tahlili (analitis). ${ }^{4}$

Mekanisme penafsiran dengan metode ijmali dilakukan dengan cara menguraikan ayat demi ayat, serta surah demi surah yang ada dalam al-Qur'an secara sistematis. Semua ayat ditafsirkan secara berurutan dari awal sampai akhir secara ringkas dan padat dan bersifat umum. Uraian yang dilakukan dalam metode ini mencakup beberapa aspek uraian terkait dengan ayat-ayat yang ditafsirkan, antara lain :

a. Mengartikan setiap kosa kata yang ditafsirkan dengan kosa kata yang lain yang tidak jauh menyimpang dari kosa kata yang ditafsirkan.

b. Menjelaskan konotasi setiap kalimat yang ditafsirkan sehingga menjadi jelas.

c. Menyebutkan latar belakang turunnya (asbab al-nuzul) ayat yang ditafsirkan, walaupun tidak semua ayat disertai dengan asbab al-nuzul. Asbab al-nuzul ini dijadikan sebagai pelengkap yang memotivasi turunnya ayat yang ditafsirkan. Asbab al-nuzul menjadi sangat urgen, karena dalam asbab al-nuzul mencakup beberapa hal yaitu, peristiwa, pelaku dan waktu.

d. Memberikan penjelasan dengan pendapat-pendapat yang telah dikeluarkan berkenaan dengan tafsiran ayat-ayat tersebut, baik yang disampaikan oleh Nabi, sahabat, tabi'in maupun tokoh tafsir.

Dalam kaitannya dengan metode terjemah yang digunakan oleh A. Hassan. Menurut Kamus Besar Bahasa Indonesia, kata "terjemah" diartikan dengan menyalin (memindahkan) suatu bahasa ke bahasa lain; mengalihbahasakan; salinan bahasa; alih bahasa (dari suatu bahasa ke bahasa lain). ${ }^{4}$

Dalam bahasa Arab, al-Zarqānī mengemukakan bahwa kata (terjemah) memiliki beberapa pengertian yaitu;

a. تبليغ الكلارم لمن مي يبلغ yaitu menyampaikan suatu perkataan kepada yang belum sampai kepadanya.

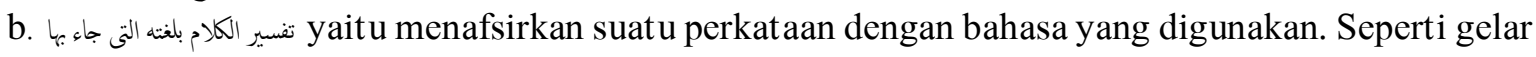
yang disandang oleh Abdullah ibn 'Abbas sebagai Tarjuman al-Qur'an.

c. تنسير الكلام بلغة غير لغته yaitu menafsirkan suatu perkataan dengan bahasa yang bukan bahasa yang digunakan.

d. نقل الكلام من غنة إلى أخرى yaitu memindahkan kalimat dari satu bahasa ke bahasa lain (alih bahasa).

Sedangkan menurut al-Zahabī, bahwa kata "terjemah" menurut bahasa memiliki dua pengertian;

${ }^{4}$ Metode $\operatorname{tah}$ Tifi adalah suatu metode tafsir yang mufassirnya berusaha menjelaskan kandungan ayatayat al-Qur'an dari berbagi segi dengan memperhatikan urutan ayat-ayat al-Qur'an sebagaimana yang tercantum di dalam mushaf. Lihat M. Quraish Shihab, Membumikan al-Quran (Cet. XIX; Jakarta: Mizan, 1999), h. 86.; Ahmad al-Syarbāsyì, Qișșah al-Tafsīir (Beirut: Dār al-Jail, t.th.), h. 232.; Said Agil Munawwar, I'jaz al-Qur'an dan metodologi Tafsir (Cet. I; Semarang: Dina Utama, 1994 M), h. 36.; Dawam Raharjo, Paradigma al-Qur'an (Cet. I; Jakarta PSAP Muhammadiyah, 2005 M), h. 68.

${ }^{4}$ Tim Penyusun Kamus Pusat Bahasa, Kamus Besar Bahasa Indonesia (Jakarta: Pusat Bahasa, 2008), h. 1693.

${ }^{5}$ Muhammad 'Abd al-'Azim al-Zarqānī, Manāhil al-'Irfăn fi 'Ulūm al-Qur'ān, Jilid II (Mesir: Dar Ihya al-Kutub al-Arabiyah, 1980) h. 109-110. 
a. تنل الكلام من لغة إلى لغة أخرى بدون بيان لمعنى الأصل المترجم yaitu memindahkan kalimat dari satu bahasa ke bahasa lain tanpa menjelaskan makna asli yang diterjemahkan. Seperti menempatkan kalimat sinonim dalam satu bahasa.

b. تنسير الكلامو بيان معناه بلغة أخرى yaitu menafsirkan suatu perkataan dan menjelaskan maknanya dengan bahasa yang lain (di luar bahasa Arab). ${ }^{5}$

Sedangkan menurut istilah adalah; التبعير من معنى كلام فى لغة بكلام آخر من لغة أخرى مع الوفاء بحميع معانيه و مقاصده

Yaitu mengungkapkan pengertian kalimat dalam suatu bahasa dengan kalimat bahasa lain lengkap dengan seluruh pengertian dan maksud-maksudnya.

Sementara penggunaan istilah menterjemah al-Qur'an, baik al-Zarqani maupun al-Zahabi, keduanya membagi ke dalam dua bagian, yaitu:

a. Terjemah Harfiyah, yaitu terjemah yang susunan dan urutan-urutan kata-katanya selalu terpelihara keasliannya, sehingga disamakan dengan meletakan kata-kata persamaan (sinonim) dengan sinonimnya ke dalam bahasa baru. Sebagian orang menyebut terjemahan ini dengan terjemah lafziyah (letterlijkl).

b. Terjemah Tafsiriyah, yaitu terjemah yang tersusun dan urutan-urutan kata-katanya tidak terpelihara. Yang diperhatikan ialah gambaran pemahaman yang baik dan tujuan-tujuannya secara sempurna. Terjemah ini disebut juga dengan terjemah maknawiyah. Penyebutan tafsiriyah karena baiknya gambaran pemahaman (pengertian) dan tujuan-tujuannya sehingga menyerupai tafsir, namun bukan tafsir. ${ }^{5}$

Dengan demikian, bahwa makna dari terjemah harfiyah di sini bahwa al-Qur'an tetap dalam bentuk asli Arabnya, sebagaimana dalam mushaf. Setelah al-Qur'an diterjemahkan, al-Qur'an dalam bentuk yang kedua ini merupakan hasil ijtihad yang mencoba memahami dan mengalihbahasakan bahasa al-Qur'an ke dalam bahasa manusia. Di sinilah kerja penerjemah mempunyai kesamaan yang asasi dengan kerja penafsir (mufassir). Yang mana dengan menggunakan ijtihad dalam menerjemahkan suatu ayat dalam hal memilih makna yang tepat, seperti halnya dalam terjemah maknawiyah yang disebut juga terjemahan tafsiriyah. Sehingga boleh jadi dengan adanya penerjemahan maknawiyah inilah yang menyebabkan tafsir al-Furqan disebut sebagai kitab tafsir.

Hal ini sejalan dengan pandangan Nashruddin Baidan yang menyatakan bahwa dari segi fungsinya, terjemahan dapat dikatakan sama dengan tafsir, namun bila diamati secara seksama, terjemahan hanyalah sekedar alih bahasa. Artinya bahwa informasi yang diberikan hanya sebatas ayat yang diterjemahkan, tanpa member penjelasan yang rinci. Sedangkan tafsir berusaha memberikan penjelasan yang memadai tentang ayat yang dibicarakan, sehingga tergambar dalam benak pembaca dan pendengar akan kedalaman dan keluasan makna yang dikandung oleh ayat yang ditafsirkan. ${ }^{5}$

Sebagai contoh bahwa suatu kata dalam bahasa Arab terlalu kompleks untuk dimaknai dengan bahasa Indonesia, yang pada banyak bagian masih terbatas dalam memberikan padanan terhadap konsep kata dalam bahasa Arab. Misalnya kata خوف (khauf) dan kata خشية (khasyah) yang keduanya dalam bahasa Indonesia diartikan "takut". Bila dilihat masing-masing kata mempunyai konsekuensi semantik yang berbeda. Kata خشية (khasyah) mempunyai nilai cakupan semantik lebih tinggi daripada kata خوف (khauf). Kata خشية (khasyah) mengandung arti "rasa takut yang besar bercampur baur dengan rasa hormat, meskipun orang yang takut itu adalah orang kuat", sedangkan

${ }^{5}$ Muhammad Ḥusain al-Zahabi, Al-Tafsir wa al-Mufasșirun, Jilid I (Cet. II; Mesir: Dar al-Ma'rifah, 1396H/1976M), h. 23

${ }^{5}$ Muhammad 'Abd al-'Azim al-Zarqānī, Manāhil al- 'Irfăn fì 'Ulūm al-Qur'ān, h. 111.

${ }^{5}$ Muḥammad 'Abd al-'Azim al-Zarqānì, Manāhil al-'İ̉ān fī 'Ulūm al-Qur'ān, h. 111.; Lihat juga Muhammad Husain al-Zahabi, Al-Tafsir wa al-Mufassirun, h. 23-24.

${ }^{5}$ Nashruddin Baidan, Wawasan Baru Ilmu Tafsir (Cet. fl; Yogyakarta: Pustaka Pelajar, 2011), h. 6970. 
خوف kata (khauf) lebih berarti "ketakutan yang disebabkan oleh ketakutan orangnya, meskipun sesuatu yang ditakuti itu bukanlah hal yang layak untuk ditakuti". ${ }^{5}$

Berangkat dari kenyataan ini, maka salah satu upaya untuk mengatasinya dan sekaligus menghindari kekeliruan dalam pemahaman al-Qur'an adalah melengkapi terjemahan dengan penjelasan singkat terhadap ayat yang diterjemahkan. Dengan demikian makna harfiyah dalam tafsir al-Furqān ini adalah pengalihan bahasa yang mengindikasikan kepada tafsiran ayat dengan metode pemilihan arti kata yang sesuai dan mengena untuk menghasilkan makna yang dapat dimengerti.

Namun dalam menerjemahkan al-Qur'an, menurut al-Zahabi, hendaknya juga terpenuhi syarat-syarat sebagai berikut;

a. Terpenuhi syarat-syarat penerjemahan sebagaimana syarat-syarat yang harus terpenuhi dalam tafsir yaitu di antaranya; harus berlandaskan dari hadis-hadis Nabi saw., penguasaan ilmu bahasa Arab, dasar-dasar (ilmu usul) yang telah ditetapkan dalam syariat Islam. Terjemah harus mewakili semua arti dan maksud bahasa asli secara lengkap.

b. Penerjemah harus melepaskan dan menjauhkan diri dari kecenderungan kepada kepercayaan yang palsu yang bertentangan dengan al-Qur'an. Agar supaya penerjemah tidak menerjemahkan sesuai kecenderungan yang dia miliki.

c. Penerjemah harus mengetahui dua bahasa yaitu bahasa aslinya (Arab) dan bahasa yang diterjemahkan, mendalami dan menguasai uslub-uslubnya.

d. Penerjemah harus menuliskan terlebih dahulu ayat al-Qur'an yang asli, lalu menafsirkan, setelah itu dikemukakan terjemah tafsiriyah. ${ }^{5}$

Berdasarkan uraian ini, bahwa tafsir dan terjemahan berbeda secara definisi dan juga penempatannya. Jika tafsir mengurai makna-makna, hukum-hukum dan hikmahnya, maka terjemah hanyalah sebatas memindahkan bahasa al-Qur' an ke dalam bahasa-bahasa lainnya, seperti misalnya dalam bahasa Indonesia at au bahasa non Arab.

Sehingga metode harfiyah yang dimaksud adalah metode dalam penerjemahan, bukan dalam penafsiran. Seperti yang telah diuraikan di atas, dalam penerjemahan ini A. Hassan cenderung memakai metode terjemah harfiyah dan kemudian ada beberapa bagian yang diterjemahkan secara maknawiyah. Dan berdasarkan apa yang ditulis mengenai metode yang dipakai, dapat dilihat catatan yang ditulis A. Hassan dalam al-Furqān. Catatan-catatan tersebut hanya menjelaskan maksud ayat yang kurang jelas, secara singkat dan umum. Melihat dari sana, maka metode yang dipakai oleh A. Hassan dalam menafsirkan al-Qur'an adalah dengan memakai metode ijmali.

Sedangkan metode ijmali A. Hassan ini terkesan hanya seperti terjemah biasa yang diberikan catatan-catat an kecil dalam bentuk footnote. Dan tafsir al-Qur'an ini hanya seperti terjemah alQur'an biasa, pembacanya belum dapat memahami apa-apa, atau sebatas apa yang difahami dalam terjemahnya saja. Adapun yang tersirat di dalam ayat-ayat al-Qur'an yang sarat dengan makna, tidak atau belum didapatkan secara eksplisit dan tidak dapat diungkap secara konprehensif.

\subsubsection{Kandungan Tafsirnya}

Berikut penulis akan memaparkan beberapa contoh kandungan tafsir dengan dengan memulai dari QS. al-Fatihah/1: 1-7, sebagai berikut;

AL-FATIHAH

Pembukaan

Surah ke-1, 7 Ayat

${ }^{5}$ Masmu' Ahmad Abu Talib, Khulāsat al-Bayān fi Mabăhis 'min 'Ulūm al-Qur'ān (Cet. I; Kairo: Dār al-Tibā'ah al-Muhammadiyah, 1994), h. 198.

${ }^{5}$ Lihat Muhammad Husain al-Zahabi, Al-Tafsir wa â-Mufassirun, h. 29-30. Lihat juga Rosihan Anwar, Ulum al-Qur'an (Cet. II; Bandung: CV. Pustaka Setia, 2010), h. 213. 
Diwahyukan di Mekah

Mukadimah

Surah ini berisi penjelasan tentang (1) keimanan kepada Allah yang telah menganugerahkan beragam kenikmatan, (2) jalan kebahagiaan, dan (3) kisah para nabi dan para penentang Allah. Semua penjelasan dari ketiga hal tersebut terdapat di dalam berbagai ayat pada surah yang lain di dalam al-Qur'an.

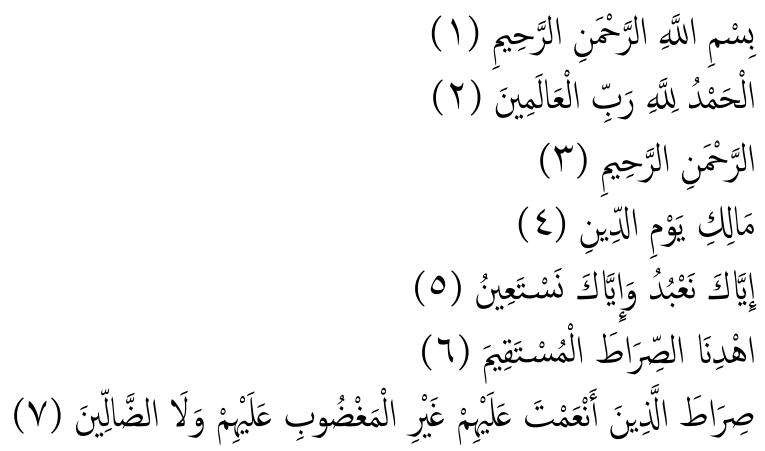

Dengan menyebut nama Allah Yang Maha Pemurah lagi Maha Penyayang

Segala puji (hanyalah) milik Allah, Tuhan alam semesta

Yang Maha Pengasih lagi Maha Penyayang

Yang Menguasai hari Pembalasan

Hanya Engkaulah yang kami sembah dan hanya kepada-Mulah kami memohon pertolongan

Tunjukkanlah kami jalan yang lurus. (yaitu) jalan orang-orang yang Engkau anugerahi nikmat, bukan (jalan) mereka yang dimurkai dan bukan (pula jalan) mereka yang sesat. ${ }^{5}$

Tafsir al-Furqān ini dimulai dengan menafsirkan surah al-Fatihah, sebagaimana kitab tafsir yang lainnya. Terlebih dahulu A. Hassan mengemukakan nama surah dan artinya, jumlah ayat dan tempat diwahyukan kemudian menulis muqaddimah yang berisi tentang kandungan ayat-ayatnya, setelah itu barulah menulis ayat di bagian kanan disertai terjemahan dari surah yang akan ditafsirkan yang diletakkan di bagian kiri. Bila ada yang perlu dijelaskan lebih lanjut, A. Hassan menerangkannya di bagian catatan kaki (footnote).

Secara spesifik, A. Hassan memberi komentar mengenai surah al-Fatihah dalam bukunya Sual-Djawab, ketika diperdebatkan mengenai apakah pahala bacaan surah al-Fatihah tersebut benar-benar sampai kepada roh yang sudah mati yang ditujukan. A. Hassan menolak dengan tegas menolak kepercayaan ini dengan mengatakan bahwa Imam al-Syafi'i sendiri menyatakan pahala bacaan al-Fatihah dan tahlilan itu sendiri tidak akan sampai kepada roh orang yang sudah meninggal. ${ }^{5}$

Contoh lainnya dalam QS. al-Fìl/105: 1-5; dan QS. Quraiys/106: 1-4. Dari kedua surah ini, ada perbedaan yang signifikan yaitu dalam QS. al-Fil, A. Hassan menjelaskan sejarah tentara Habasyah yang mengendarai gajah untuk menghancurkan Ka'bah. Sedangkan dalam QS. Quraisy, ia tidak menjelaskan penafsiran dalam catatan kakinya. Yang boleh jadi, ketika seseorang membaca terjemahannya saja, dianggap sudah cukup memadai penjelasannya.

${ }^{5}$ A. Hassan, Al-Furqān Tafsir Qur'an, h. 1.

${ }^{5}$ Lihat A. Hassan, Sual-Djawab, Vol. I (Bangil, Persatuån Islam Bagian Pustaka, 1958), h. 29. Hal ini terkait dengan praktik "tawassul" yang sering dilakukan dalam penyelenggaraan selamatan, dan tahlilan sebagai ritual utamanya. Ritual ini biasanya dimulai dengan bacaan surah al-Fatihah, yang pahalanya dihadiahkan kepada roh Nabi Muhammad saw., Syekh 'Abdul Qadir Jailani, para waliullah dan roh orang yang dihormati serta roh para nenek moyang dari keluarga yang bersangkutan. Dengan menghadiahkan pahala bacaan surah al-Fatihah ini kepada roh para tokoh tersebut, doanya diyakini akan mudah dikabulkan oleh Allah swt. Lihat juga Fauzan Saleh, Teologi Pembaruan; Pergeseran wacana Islam Sunni di Indonesia Abad $X X$, h. 199. Mengenai tawassul dan segala problematikanya dapat dilihat juga Ahmad Hakim, Tawassul dalam Perspektif al-Qur'an (Desertasi, UIN Alauddin Makassar, 2012), h. 30. 
Dalam metode terjemahan harfiyah yang digunakan oleh A. Hassan dalam tafsirnya, sebagaimana telah disebutkan di atas- ia juga menggunakan metode terjemah maknawiyah atau tafsiriyah, sebagai contoh dalam QS. al-Isra' atau QS. Bani Isra'il (17): 29. Dalam ayat ini diterjemahkan dengan "dan jangan jadikan tanganmu terbelenggu di tengkukmu" yang kemudian ditafsirkan di bagian catatan kakinya, maksudnya adalah; "janganlah kamu menjadi orang yang kikir dan bakhil", lalu terjemahan "dan jangan terlalu mengulurkannya", ditafsirkan dengan "jangan terlalu mudah dan murah dalam mengeluarkan sesuatu". Dalam hal ini, bila suatu ayat membutuhkan penjelasan dari terjemahannya, ia sangat memperhatikan agar dapat difahami dengan menafsirkannya di bagian catatan kakinya.

Hal inilah yang dapat difahami dalam metode terjemah maknawiyah atau tafsiriyah yang digunakan oleh A. Hassan, sehingga kitab ini digolongkan sebagai kitab tafsir.

\section{Penutup}

\subsection{Kesimpulan}

Dari pembahasan dan kajian ini dapat disimpulkan sebagai berikut;

a. Ahmad Hassan dapat dikategorikan sebagai tokoh penting dalam sejarah perkembangan tafsir di Indonesia. Beliau adalah ulama multi dimensi, baik sebagai ulama, pedagang, pengkader maupun sebagai penulis. Tak kalah pentingnya dia juga salah seorang tokoh dan guru Persis (Persatuan Islam). Lahir di Singapura tahun 1887, dan wafat pada tanggal 10 November 1958. Tokoh kharismatik ini meninggal dunia pada usia 71 tahun di Bangil (Jawa Timur), dan dimakamkan di Pekuburan Segok, Bangil.

b. Al-Furqān Tafsir al-Qur'an sebagai karya monumentalnya ditulis dalam kurun waktu tahun 1920-1950-an, dengan berbagai edisi dan terakhir diterbitkan ulang dalam edisi mutakhir dan mengikuti bahasa Indonesia modern oleh tim penyunting dari Universitas al-Azhar Indonesia (UAI) Jakarta. Kitab tafsir ini terdiri dari 1 jilid dan mencakup penafsiran seluruh ayat suci alQur'an 30 juz.

c. Metode yang digunakan dalam tafsirnya adalah metode terjemahan harfiyah, meski pada beberapa penafsirannya terdapat pula terjemahan maknawiyah. Dari metode penafsirannya yang menjelaskan ayat-ayat al-Qur'an cenderung ringkas dan padat, maka dapat dikatakan bahwa metode yang digunakan dalam tafsir ini termasuk dalam kategori metode tafsir ijmali.

\subsection{Implikasi}

Studi atas al-Furqān Tafsir Qur'an mestinya harus banyak dikaji oleh para akademisi, mahasiswa dan masyarakat umum. Agar kajian ini lebih mendalam lagi sehingga khazanah dan sejarah tafsir di Indonesia tidak statis dan vakum atau berhenti. Meski didapatkan dalam prosesnya, didapatkan buktinya bahwa ternyata karya tafsir ini masih terbatas dibaca hanya di kalangan akademisi, olehnya itu masih perlu disosialisasikan lebih luas lagi.

Dan melalui kajian ini diharapkan tumbuh kesadaran untuk mengembangkan kajian tafsir, khususnya memperkenalkan kembali al-Furqan Tafsir Qur'an karya A. Hassan ini di tengah-tengah masyarakat. 


\section{DAFTAR PUSTAKA}

Al-Qur'an al-Karim

A. Hassan Al-Furqān Tafsir Qur'an Cet. II; Jakarta: Universitas Al-Azhar Indonesia, 2010. ,. Sual-Djawab, Vol. I Bangil, Persatuan Islam Bagian Pustaka, 1958.

Anwar, Rosihan. Ulum al-Qur'an Cet. II; Bandung: CV. Pustaka Setia, 2010.

Baidan, Nashruddin. Metode Penafsiran al-Qur'an Cet. II; Yogyakarta: Pustaka Pelajar, 2011. -----.. Wawasan Baru Ilmu Tafsir Cet. II; Yogyakarta: Pustaka Pelajar, 2011.

Dahlan (ed), Abdul Aziz. Ensiklopedi Hukum Islam, Jilid 2 Cet. I; Jakarta: Ichtiar Baru Van Hoeve, 1996.

Kementerian Agama RI, Al-Qur'an dan Terjemahnya al-Madinah al-Munawwarah: Mujamma' alMalik Fahd li al-Ṭibā'āt al-Muṣhaf, $1418 \mathrm{H}$.

Al-Farmāwī, 'Abd Hayy. Muqaddimah fí al-Tafsìir al-Maudūíi Cet. III; t.t: tp, 1409 H/1988 M.

Hakim, Ahmad. Tawassul dalam Perspektif al-Qur'an Desertasi, UIN Alauddin Makassar, 2012.

http://lembaranpersisbangil.blogspot.com/2010/10/biografi-hassan.html. Sunday, October 31, 2010 (diakses tg1 27 Nopember 2012).

Imroni, Mohammad Arja. Konstruksi Metodologi Tafsir al-Qurthubi Cet.I: Semarang: Walisongo Press, 2010.

Mughni, Syafiq A. Hassan Bandung: Pemikir Islam Radikal Cet. II; Surabaya: PT. Bina Ilmu, 1994M.

Munawwar, Said Agil. I'jaz al-Qur'an dan metodologi Tafsir Cet. I; Semarang: Dina Utama, 1994 M.

Qadir, Zuhal Abdul. Sepatah Kata dari Kami, dalam A. Hassan, Al-Furqān Tafsir Qur'an Cet. II; Jakarta: Universitas Al-Azhar Indonesia, 2010.

Rahardjo, Dawam. Paradigma al-Qur'an Cet. I; Jakarta PSAP Muhammadiyah, 2005 M.

Saleh, Fauzan. Teologi Pembaruan; Pergeseran wacana Islam Sunni di Indonesia Abad XX Cet. I; Jakarta: PT. Serambi Ilmu Semesta, 2004.

Salim, Abdul Muin. Metodologi Tafsir; Sebuah Rekonstruksi Epistemologis Memantapkan Keberadaan Ilmu Tafsir sebagai Disiplin Ilmu, Orasi Ilmiah Pengukuhan Guru Besar Ujungpandang: IAIN Alauddin, 1999.

Sewang, Ahmad M. Syekh Yusuf; Ulama Pejuang Yang Energik (1626-1699), Makalah Seminar Syekh Yusuf PKB Wilayah Sulawesi Selatan, Makassar 25 Juli 2011.

Shihab, M. Quraish. Membumikan al-Quran Cet. XIX; Jakarta: Mizan, 1999.

Suryadilaga (dkk), M. Al-Fatih. Metodologi Ilmu Tafsir Cet. III; Yogyakarta: Teras, 2010.

Al-Syarbāsyì, Ahmad. Qișsah al-Tafsīir Beirut: Dār al-Jail, t.th.

Ṭalib, Masmu' Ahmad Abu. Khulāsat al-Bayān fi Mabāhis 'min 'Ulūm al-Qur'ān Cet. I; Kairo: Dār al-Tibā' ah al-Muhammadiyah, 1994.

Tim Penyusun Kamus Pusat Bahasa, Kamus Besar Bahasa Indonesia Jakarta: Pusat Bahasa, 2008. www.maulana2008.co.cc (diakses tgl 27 Nopember 2012)

Al-Zahabi, Muhammad Ḥusain. Al-Tafsir wa al-Mufassirun, Jilid I Cet. II; Mesir: Dar al-Ma'rifah, 1396H/1976M.

Al-Zarqānī, Muhammad 'Abd al-'Azim. Manāhil al-'Irfān fì 'Ulūm al-Qur'ān, Jilid II Mesir: Dar Ihya al-Kutub al-Arabiyah, 1980. 